\title{
Modernization of the Tax Administration System: A Theoretical Review of Improving Tax Capacity
}

\author{
Taufik Kurniawan ${ }^{1}$ \\ ${ }^{1}$ Indonesia Parliamentary Board, Jl. Jenderal Gatot Subroto RT.1/RW.3, Senayan, \\ Kebayoran Baru, RT.1/RW.3, Gelora, Kota Jakarta Selatan, Daerah Khusus Ibukota Jakarta 10270
}

\begin{abstract}
The canons of transaction theory requires taxation to rest on the principles of justice, certainty, comfort, and economics. However, as the government continues to demand for development finance and increasingly depend on tax revenues, the aforementioned principles have been neglected in taxation as can be empirically observed in the complaints, tax avoidance efforts, and tax revenue in Indonesia. The lower tax revenues of Indonesia compared with those of other countries indicate that the tax reforms implemented in the country from 1984 to date have produced sub-optimal results and require realignment. The reformation or modernization of a tax administration system aims to improve the effort or performance of tax collecting authorities. Such reformation may be conducted individually or by group to achieve more efficient, economical, and rapid outcomes. The modernization process focuses on organizational structure, procedure, strategy, and culture. In order for such modernization process to succeed, the tax structure must be simplified, appropriate reform strategies must be developed, and a strong political commitment to reforming the tax administration system must be ensured.
\end{abstract}

Keywords: Modernization; Tax Administration System; Fiscal Capacity

\section{Introduction}

From 1983 to 1985 , Indonesia has attempted to reform its tax administration system by enacting several tax laws that, in principle, transfer the task of tax collection from official tax collection systems to selfassessing collection systems. The goal of these laws is to increase the tax capacity of the country.

The tax capacity of Indonesia is still unbearably low in 2016 as reflected in the results of the 2016 OECD survey, which places the tax ratio of Indonesia in a much lower position compared with that of other Asian and ASEAN countries. Specifically, the tax ratio of Indonesia is only $10.8 \%$, which is lower than those of Malaysia and Thailand, which ranges from $11 \%$ to $13 \%$. This ratio is also much lower than that of Australia (22.2\%), France (23.3\%), and the UK (25.0\%). However, this tax ratio clearly reflects the contribution of tax revenue to the total state revenue. For example, in 2016, the tax revenue of Indonesia only amounted to Rp $1,105.9$ trillion or only $81.6 \%$ of its target Rp $1,355.2$ trillion. These data indicate that Indonesia completely relies on taxes as its main revenue and is unable to increase its tax capacity.

Tax capacity reflects the level of taxpayer compliance, which is triggered by the quality of service that taxpayers receive from tax authorities. Tax compliance has always been a major issue of taxation in many countries [1].

Pandiangan [2] and Zain [3] revealed that low tax compliance could be influenced by the taxation ability of authorities. Therefore, establishing a tax administration system that provides an excellent quality of service can improve taxpayer compliance.

In sum, a better tax administration system will encourage taxpayers to improve their compliance and consequently increase the tax revenues of an economy. Establishing an efficient and "modernized" tax administration system presents one way of improving taxpayer compliance, which in turn increases tax capacity.

Corresponding author email: tk.taufikkurniawan@gmail.com 


\section{Methodology}

This paper adopted the descriptive qualitative method, while the data were collected using library data collection techniques and documentation studies.

\section{Discussion}

To modernize tax administration, one must establish a tax administration system that puts forward the principles of good governance and can promote taxpayer compliance. Governments must first understand the behavior of taxpayers who tend to avoid paying their taxes and that of government officials who tend to neglect doing their jobs. Understanding such behavior can help us determine which tax administration model must be developed. Zain ${ }^{3}$ assumed six patterns of paying taxes (by taxpayers) and tax management (by tax authorities).

First, taxpayers always strive to pay the smallest possible amount of tax as long as allowed by the provisions of tax legislation on tax avoidance and/or tax savings. Second, taxpayers tend to engage in tax smuggling in the form of unilateral and bilateral evasion as long as they have a convincing reason to do so. Third, taxpayers are neither worried nor afraid of tax regulations and administrative sanctions and try to exploit the weaknesses of the present tax administration system. Fourth, taxpayers seek to influence tax officials with persuasion, temptation, and sometimes threats. Fifth, tax administrators have a fundamental aversion to reviewing the errors in tax decisions. Sixth, tax officers often act beyond their function and authority as well as fail to carry out their duties.

The above assumptions highlight the need to adopt a taxation approach that can address the reluctance of taxpayers to pay their taxes and the reluctance of fiscal officers to establish and manage efficient tax companies. One of the essential theories in the field of taxation is the four canons of taxation introduced by Adam Smith (1723-1790) in his book, An Inquiry into the Nature and Causes of the Wealth of Nations.

Suandi (2005) put forward four tax collection principles that must be developed, thus: (1) the principle of justice, which suggests that the amount of tax levied must be balanced with the ability of the taxpayer to pay; (2) the principle of certainty, which suggests that taxes must have a clear measure of certainty concerning their subjects, objects, rates, and preferred payments; (3) the principle of comfort, which suggests that the tax must be collected at the most appropriate and convenient time for the taxpayer; and (4) the principle of economics, which suggests that taxes must be collected in an efficient manner and that the tax collection fees must not be greater than the tax revenue itself.

According to Sommerfeld et al. as published in Zain $^{3}$, the criteria for designing a taxation system must no longer be limited to the four canons of taxation but must integrate the three principles of productivity, visibility, and political considerations.

The four canons of taxation aim to improve the standard of service that fiscals need to implement and provide the basis for fiscals to reform their business processes through a number of approaches based on service acceleration, transparency, accountability, and adoption of information technology. If these officials neither show any effort in reforming the tax administration system nor acknowledge the importance of modernizing this system, then all of the above assumptions will remain in the minds of taxpayers. Modernizing the tax administration system has become a necessity even long before taxation has become a modern concept in our lives. The modernization of the tax administration system must be able to integrate the principles of justice, certainty, comfort, and economics into the tax administration process. Philosophically, the four canons of taxation serve as the main foundations in modernizing the tax administration system of Indonesia. In 2002, the Government of Indonesia, through the Directorate General of Taxes (DGT), launched a program to reform or modernize its tax administration system. The objectives of modernization are: (1) to achieve a high tax compliance level, (2) to encourage trust toward the current tax administration, and (3) to achieve a high employee tax productivity level. These three objectives are designed to be achieved by providing excellent service and by intensively supervising the taxpayers.

The modernization of the tax administration system must be designed and implemented thoroughly and comprehensively. The government has implemented several changes in the following areas: (1) organizational structure; (2) business process and information and communication technology; (3) human resource management; and (4) implementation of good governance.

The findings of this research show a huge change in the tax administration system, tax revenue, and taxpayer compliance in Indonesia as a result of modernization. However, when compared with Asian and ASEAN countries, the impact of modernization on the tax administration system of Indonesia is unbalanced. However, although moving toward the right direction, the modernization of the tax administration system of Indonesia needs to be maintained and reinforced.

Nasucha [4] revealed that the reform or modernization of the tax administration system can improve tax administration performance either individually or by group as well as make the tax collection process more efficient, economical, and fast. To reform or modernize the tax administration system successfully, the following elements need to be present: (1) simplified tax structures to achieve an easy tax collection process, to promote taxpayer compliance, and to facilitate tax administration; (2) appropriate reform strategies; and (3) strong political commitment to an improved tax administration.

In addition, in the context of tax administration reform is also required changes in performance measurement indicators tax revenue that is not solely oriented to acceptance. According to Crandall [5], the strategic objectives of tax authorities must include 
improving taxpayer compliance, improving tax collection efficiency and productivity, and enhancing service orientation to ensure that the collected tax money is sufficient for government spending. Other indicators, such as administrative cost, service satisfaction of taxpayers, coverage of tax socialization, effectiveness of the examination until the dispute settlement, are equally important in the success of the reform/modernization of the tax administration system.

In line with the philosophical and theoretical development of the concept above, modernizing the tax administration system can improve taxpayer compliance, which in turn will have implications for increasing tax capacity. Such influence was first proven in Hutagaol et al [6], who compared the experiences of various countries, such as Jamaica and New Zealand, and concluded that taxpayer compliance is often affected by data limitations. By using data in 2006, their research on Indonesian taxation showed that improving the quality of the tax information system, as a way of modernizing the tax administration system, could increase taxpayer compliance and tax capacity simultaneously.

The findings of Hutagaol et al [6] were repeated in Rahayu and Lingga (2009). By conducting their study from the perception of taxpayers in a tax office (KPP) in the city of Bandung, Rahayu and Lingga (2009) found that modernizing the tax administration system, especially utilizing an integrated tax administration system (SIAPT), could improve taxpayer compliance. The same influence was observed by Setiana and Agustina (2011), who examined a KPP office in Bandung. Related studies published from 2007 to 2011 have shown consistent results, thereby confirming a very strong theoretical relationship between modernizing the tax administration system and increasing the tax capacity of Indonesia. The concept of tax reform is also applicable in the slightly different contexts of some countries. Martinez and McNab [7] and Emran and Stiglitz [8] found that the tax reforms in some developing countries had a positive impact on improving prosperity, reducing poverty, increasing economic added value, and increasing other measures of social welfare.

Many studies have been conducted in various regions of Indonesia over the past three years (20132016). For example, Candra and Wibisono [9], in their article published in the Journal of Management \& Accounting Research, proved that modernizing the tax administration system could improve taxpayer compliance. Accordingly, their findings have been frequently cited in subsequent research. The studies of Doni [10] in Semarang, Rochmah [11] and Listriana [12] in Surabaya, and Arifin [13] in Jakarta all show that modernizing the tax administration system of Indonesia can improve taxpayer compliance.

\section{Conclusion}

In line with the results of philosophical, theoretical, and empirical analyses conducted by several studies over the past years, modernizing the tax administration system can increase the tax capacity of an economy and serve as a measure of improvement in taxpayer compliance. Although the tax capacity of Indonesia remains at a low level as mentioned in the Introduction, this paper conceptually shows that tax reform or tax administration modernization has an important role in increasing the tax capacity of the country. The program launched by DGT in 2002 can be maintained and improved by evaluating the four principles of taxation, namely, the principles of justice, certainty, comfort, and economics, as references in reviewing the future development of tax administration modernization.

Increasing tax capacity should have an impact on environmental welfare, this can be seen from how the government provides a budget for environmental conservation in order to create a good environment.

\section{References and Notes}

1. I. N. Sudiarta, "Panama Papers dan Praktik Penghindaran Pajak", https://www.cnnindonesia.com, retrieved 31 Agustus 2017 (2017).

1. L. Pandiangan, "Modernisasi dan Reformasi Pelayanan Perpajakan", Jakarta, PT Elex Media Komputindo (2008).

2. M. Zain, "Manajemen Perpajakan", Jakarta, Salemba Empat (2003).

3. V. Nasucha, Reformasi Administrasi Publik: Teori dan Praktik, Jakarta, PT Gramedia Widiasarana Indonesia (2004).

4. W. Crandall, "Revenue Administration: Performance Measurement in Tax Administration", IMF Technical Notes and Manuals (2010).

5. J. W. Hutagaol, \& A. Pradipta, "Strategi Meningkatkan Kepatuhan Wajib Pajak, Jurnal Akuntabilitas", 6(2), 186-193 (2007).

6. J., Martinez-V, \& R. M. McNab, "The Tax Reform Experiment in transitional countries. National Tax Journal”, 273-298 (2000).

7. M. S. Emran, \& J. E. Stiglitz, "On Selective Indirect Tax Reform In Developing Countries. Journal of Public Economics", 89(4), 599-623 (2005).

8. R. Candra, \& H. Wibisono, "Modernisasi Sistem Administrasi Perpajakan \& Kepatuhan Wajib Pajak", Jurnal Riset Manajemen \& Akuntansi, 1(1), 1-9 (2013).

9. P. G. Doni, "Upaya Modernisasi Sistem Administrasi Perpajakan Terhadap Kepatuhan Wajib Pajak (Studi Kasus Pada Kpp Pratama Semarang Timur)", Skripsi, Fakultas Ekonomi \& Bisnis Undip (2015).

10. A. Rochmah, "Pengaruh Penerapan Sistem Administrasi Perpajakan Modern Terhadap Kepatuhan Wajib Pajak", Jurnal Ilmu dan Riset Akuntansi, 3(10) (2015). 
11. U. Listriana, "Pengaruh Penerapan Sistem Administrasi Perpajakan Terhadap Kepatuhan Wajib Pajak", Jurnal Ilmu dan Riset Akuntansi, 3(2) (2016).

12. F. Arifin, "Pengaruh Modernisasi Sistem Administrasi Perpajakan, Kesadaran Perpajakan, Sanksi Pajak Dan Pelayanan Fiskus Terhadap
Kepatuhan Wajib Pajak Orang Pribadi”, Perbanas Review, 1(01) (2016).

13. S., En, T. K. Setiana, \& L. Agustina, "Pengaruh Penerapan Sistem Administrasi Perpajakan Modern Terhadap Kepatuhan Wajib Pajak", Jurnal Akuntansi, 2(2), P-134 (2011) 